\title{
Standard Time Analysis on The Cutting and Packaging Section of Porridge Sticky Rice “JELITA"
}

\section{Analisis Waktu Baku Pada Bagian Pemotongan dan Pengemasan Jenang Ketan "JELITA"}

\author{
Linggar Larasati ${ }^{1}$, Iffan Maflahah ${ }^{2 *}$ Burhan $^{3}$ \\ ${ }^{1,2,3}$ Program Studi Tekno logi Industri Pertanian, Fakultas Pertanian \\ Universitas Trunojo yo, Indonesia \\ e-mail*: iffanmaflahah@gmail.com
}

\begin{abstract}
ABSTRAK
Penelitian ini bertujuan untuk menentukan waktu baku kerja pada bagian pemotongan dan pengemasan jenang ketan "JELITA". Bagian pemotongan dan pengemasan merupakan bagian proses produksi yang menentukan jumlah produksi yang dihasilkan. Penentuan waktu baku dilakukan melalui melalui analisis metode kerja dan waktu kerja pada bagian - bagian tersebut. Metode yang digunakan yaitu perhitungan waktu baku dalam penentuan waktu standar peta proses operasi (PPO), peta tangan kiri, tangan kanan dan diagram aliran. Hasil penelitian menunjukkan bahwa perbaikan metode kerja berdasarkan peta kerja diperoleh berdasarkan usulan perbaikan. Usulan perbaikan menghasilkan efektifitas dan efisiensi waktu proses operasi sampai dengan layout pada sistem kerja, sedangkan pada penentuan waktu baku menghasilkan 52 detik waktu baku proses pemotongan dan 226 detik waktu baku proses pengemasan.
\end{abstract}

Kata Kunci : Diagram Aliran, PPO, Peta Tangan Kiri Kanan, Waktu Baku

\begin{abstract}
The research aims to determine the standard working time on the cutting and packaging of glutinous jenang "JELITA". The cutting and packaging part is the part of the production process that determines the amount of production produced. The determination of standard time is done through the analysis of working methods and working time in those parts. The method used is the calculation of the standard time in the determination of operating process chart, left right handed chart, and flow diagrams. The results showed that improvements in working methods based on work maps were obtained based on proposed improvements. The proposed improvement results in the effectiveness and efficiency of the operating process time up to the layout on the work system, while in the determination of the default time produces 52 seconds of the standard time of the cutting process and 226 seconds of the raw time of the packaging process.
\end{abstract}

Keywords : Flow Diagram, Left Right Hand Chart, Operation Process Chart, Standard Time.

\section{PENDAHULUAN}

Bagain penting dari suatu industri adalah metode kerja yang baik. Metode kerja dapat meliputi lingkungan kerja, prosedur atau proses produksi sampai dengan aliran stasiun kerja (diagram aliran). Metode kerja di dalam suatu industri sangatlah penting untuk diperhatikan. Metode kerja yang baik dapat menghasilkan produk yang berkualitas serta sistem kerja yang efektif dan efisien. Metode kerja sendiri dapat digunakan untuk memperbaiki sistem kerja dengan komponen utama manusia sampai dengan lingkungan kerja [5].

IRT (Industri Rumah Tangga) "JELITA" merupakan industri yang memproduksi jenang ketan. Jenang ketan yang memiliki dua lapisan warna (warna hitam dan putih). Metode kerja di industri jenang ketan "JELITA" belum optimal. Hal tersebut ditandai dengan adanya ketidakseragam produk pada bagian pemotongan dan pengemasan. Selain itu, aliran stasiun kerja yang tidak beraturan dan juga tidak adanya standar waktu baku terutama dalam proses pemotongan dan pengemasan. Oleh sebab itu, perlu dilakukan perbaikan metode kerja serta perhitungan waktu standar (waktu baku)..

Analisis Waktu Baku Bagian Pemotongan dan Pengemasan Jenang Ketan "JELITA"/ Iffan Maflahah, Linggar larasati, Burhan 
Perbaikan metode kerja dilakukan dengan menggunakan alat bantu berupa peta proses operasi (PPO), peta tangan kiri dan tangan kanan serta diagram aliran [15]. Perbaikan dilakukan berdasarkan pengamatan secara langsung. Selain itu, perhitungan waktu baku dilakukan dilakukan berdasarkan uji keseragaman data, uji kecukupan data sampai dengan penentuan faktor penyesuaiannya. Penelitian ini dilakukan berdasarkan acuan pada penelitian yag telah menerapakan perbaikan metode kerja berdasarkan waktu baku.

[1] dalam penelitiannya penentuan waktu baku digunakan sebagai penentu performansi kerja dalam memenuhi permintaan pelanggan. [8] menyebutkan bahwa penelitian tersebut dapat menentukan waktu baku dengan alat bantu berupa peta kerja tangan. Oleh sebab itu, peneliti dapat menggunakan penelitian tersebut dalam analisa perbaikan metode kerja di industri "JELITA". Metode yang digunakan dalam perbaikan metode kerja yaitu menggunakan perhitungan waktu baku.

\section{METODE}

Penelitian ini dilakukan di industri jenang ketan "JELITA" yang berlokasi di Jl. Moch. Hatta, Kecamatan Sambung, Kabupaten Tulungagung. Penelitian ini dilakukan kurang lebih selama 1 bulan. Jenis sumber data yang digunakan dalam penelitian ini yaitu data primer dan data sekunder.

Pengumpulan data primer dan sekunder, langkah selanjutnya yaitu melakukan prhitungan waktu baku. Perhitungan waktu baku dilakukan berdasarkan 200 data yang diambil pada proses pemotongan dan pengemasan jenang ketan "JELITA". Menurut [16], tahapan perhitungan perhitungan waktu baku meliputi:

\section{Uji Keseragaman Data}

Data dikatakan seragam apabila kesluruhan data yang diuji berada pada Batas Kendali Atas (BKA) dan Batas Kendali Bawah (BKB). Perhitungan BKA dan BKB dapat dilihat berdasarkan persamaan 1 dan persamaan 2 .

Persamaan tersebut menunjukkan bahwa adalah nilai rata-rata dan $\sigma$ adalah Standar deviasi sebenarnya. Rumus standar deviasi dapat dilihat pada persamaan 3.

(3)

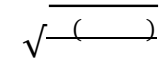

$S d(\sigma)=$ Standar Deviasi

$=$ Nilai rata-rata

$N=$ Jumlah pengukuran data

A. Uji Kecukupan Data ( $\left.N^{\prime}\right)$

Pengujian kecukupan data dilakukan berdasarkan rumus pada persamaan 4 .

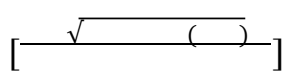

(4) Keterangan :

$=$ Kecukupan data

$N=$ Jumlah pengukuran data

= Jumah waktu penyelesaian yang teramati

=Jumah pengkuadratan waktu penyelesaian yang teramati

2. Waktu Siklus Rata-Rata (Ws)

Perhitungan waktu siklus dilakukan berdasarkan persamaan 5.

Keterangan :

$x i=$ Waktu yang dapat diperoleh untuk siklus ke-i

$i=$ Urutan siklus yang teramati

$N=$ Jumlah data pengam

Analisis Waktu Baku Bagian Pemotongan dan Pengemasan Jenang Ketan "JELITA"/ Iffan Maflahah, Linggar larasati, Burhan

Peer reviewed under responsibili of Universitas Muhammadiyah Sidoarjo.

(C) 2021 Universitas Muhammadiyah Sidoarjo. All Right reserved. This is an open access article

under the CC BY licence(http://creativecommons.org/licences/by/4.0/ ) 
Ws = Waktu Siklus

\section{Faktor Penyesuaian $(P)$}

Faktor penyesuaian di identifikasi berdasarkan kemampuan pekerja sekaligus kondisi lingkungan kerja. [13] dalam penelitian yang dilakukan berdasarkan metode westinghouse menggunakan beban kerja sampai dengan waktu standar sebagai identifikasi utama. Penelitian ini juga menggunakan metode westinghouse. Hal tersebut dikarenakan cara westinghouse merupakan cara yang memuat tentang keterampilan, usaha, kondisi kerja dan konsistensi pekerja.

\section{Waktu Normal (Wn)}

Perhitungan waktu normal ditentukan perdasarkan waktu siklus dan penentuan faktor penyesuaian. Rumus perhitungan waktuu normal dapat dilihat pada persamaa 6.

Keterangan:

Ws = Waktu siklus

$\mathrm{P}=$ Faktor Penyesuaian

\section{Kelonggaran $(A)$}

Kelonggaran diberikan berdasarkan toleransi untuk menghindari hambatan-hambatan selama melakukan pekerjaan dalam suatu sistem kerja [5]. Menurut [17] kelonggaran yang diberikan dapat berimbas pada pekerja untuk dapat bekerja secara normal.

\section{Waktu Baku (Wb)}

Persamaan perhitungan waktu baku dapat dilihat pada persamaan 7 .

$$
\text { ( ) }
$$

Keterangan :

$\mathrm{Wb}=$ Waktu Baku

$\mathrm{Wn}=$ Waktu Normal

$\mathrm{A}=$ Allowence (Kelonggaran)

\section{HASIL DAN PEMBAHASAN}

Penelitian bertujuan untuk menentukan metode kerja dan sekaligus memperbaiki metode kerja di industri "JELITA". Selain itu, penelitian ini juga dilakukan untuk menentukan waktu standar atau waktu baku dalam proses pemotongan dan pengemasan. Pemotongan dan pengemasan sendiri merupakan sistem kerja yang sangat menentukan kualitas jenang dalam segi ketahanan produk. Hasil penelitian yang dilakukan menghasikan usulan perbaikan berdasarkan peta sekarang. Usulan perbaikan tersebut berupa percepatan waktu berdasarkan peta kerja dan juga waktu standar pada proses pengemasan dan pemotongan.

\section{Peta Proses Operasi (PPO)}

Peta proses operasi sebelum dilakukan usulan perbaikan ditunjukkan dengan proses pelarutan tepung ketan dan proses penambahan bahan-bahan kering (gula, garam, dan bubuk coklat untuk adonan ketan hitam) dilakukan secara berbeda. oleh karena itu, diperlukan adanya usulan perbaikan. usulan perbaikan dapat dilakukan berdasarkan urutan operasi pada setiap komponennya. Selain itu, usulan perbaikan juga dapat dilakukan berdasarkan hubungan antara proses pada sistem kerja tanpa memperhatikan material handling yang digunakan [19].

Proses pembuatan jenang ketan di industri "JELITA" hampir sama seperti proses pembuatan jenang pada umumnya dan juga dilakukan usulan perbaikan. Usulan perbaikan didasarkan pada peta sekarang yang berupa proses penambahan bahan kering (gula, garam, bubuk coklat) yang dilakukan secara terpisah dengan proses penambahan tepung yang telah dicampur air. Perbaikan pada PPO menghasilkan penggabungan proses operasi yaitu pada proses pembuatan adonan jenang (pembuatan adonan ketan putih dan hitam sama). Usulan perbaikan dilakukan dengan penggabungan proses pelarutan (dengan air) tepung ketan yang dilakukan bersamaan dengan proses penambahan gula, garam, dan bubuk coklat untuk adonan ketan hitam. Penggabungan tersebut dimaksudkan agar tidak terdapat adonan yang menggumpal ketika proses pemasakan jenang ketan berlangsun

Analisis Waktu Baku Bagian Pemotongan dan Pengemasan Jenang Ketan "JELITA"/ Iffan Maflahah, Linggar larasati, Burhan 


\section{Diagram Aliran}

Diagram aliran dalam perbaikan metode kerja di industri "JELITA" digunakan sebagai gambaran terkait dengan informasi mendetail tentang proses kerja di industri tersebut [18]. Diagram aliran yang digunakan sebagai alat bantu dalam perbaikan metode kerja dilakukan dengan berdasarkan diagram aliran kondisi sekarang.

Diagram aliran fasilitas produksi jenang ketan "JELITA" kondisi sekarang dapat dilihat pada Gambar 1. Diagram aliran sekarang dapat digunakan sebagai identifikasi terkait adanya usulan perbaikan yang dilakukan. Berdasarkan diagram alir tersebut menunjukkan bahwa penempatan sistem kerja yang belum optimal. Hal tersebut ditunjukkan dengan letak proses pemasakan jenang yang terlalu jauh dengan sistem kerja pada bagian pemerasan santan, pendinginan sampai dengan proses pemotongan. Oleh sebab itu, perlu dilakukan perbaikan berdasarkan ketidaksesuain. Hal tersebut dikarenakan dapat mengganggu pekerja lain akibat dari proses pengangkutan bahan baku dengan jarak yang relatif jauh.

Upaya perbaikan dilakukan dengan memperbaiki fasilitas pada ruang produksi di industri jenang ketan "JELITA". Perbaikan tersebut dilakukan dengan penggabungan pada bagian pemotongan dan pengemasan yang dijadikan satu ruang dengan tempat pendinginan jenang. Hal tersebut dilakukan dengan alasan terkait dengan jarak. Jarak antara tempat pendinginan jenang yang jauh dengan tempat pemotongan dan pengemasan jenang.

Selain itu, efisiensi waktu dan efektivitas tempat pendinginan menjadi salah satu pertimbangan dalam penentuan perbaikan pada diagram aliran. Penggabungan ruang pendinginan, ruang pemasakan jenang ketan juga dilakukan usulan.

Pemindahan ruangan dapat dilakukan yaitu dengan memindahkan ruang pemasakan jenang yang berdekatan dengan ruang penghalusan bahan baku dan ruang pencetakan, pengemasan dan juga pendinginan. Usulan perbaikan dapat dilakukan dengan melihat jarak perpindahan material (berkaitan dengan ruangan) sampai dengan jarak antara pekerja dengan sistem kerjanya. Jarak antara ruangan pemasakan dengan ruangan persiapan bahan baku (bahan santan dan tepung) terlau jauh. Hal tersebut dapat menyebabkan terjadinya gerakan bolak-balik dalam proses pengambilan bahan baku yang terlalu sering dan dapat memicu kelelahan pada pekerja. Perpindahan pekerja tersebut dapat mengganggu pekerja lain yang sedang melakukan proses produk.

Perbaikan juga dapat dilihat dari segi penempatan dan penataan peralatan pada stasiun kerja untuk mengurangi jaraknya. Hal dapat dilihat dari perbaikan yang dilakukan pada sistem kerja di bagian pemasakan yang didekatkan dengan sistem kerja pada pembuatan santan ataupun tepung dan proses pendinginan jenang. Diagram aliran fasilitas produksi jenang ketan "JELITA" kondisi usulan dapat dilihat pada Gambar 2.

Perbandingan diagram aliran sebelum usulan perbaikan dilakukan berdasarkan kondisi asli di industri "JELITA". Usulan pebaikan dilakukan untuk efisiensi dan efektifitas antar ruang yang satu dengan yang lainnya. Usulan perbaikan yang dilakukan ditinjau berdasarkan segi jarak, waktu dan ketepatan aliran material yang sesuai [14]

Analisis Waktu Baku Bagian Pemotongan dan Pengemasan Jenang Ketan "JELITA"/ Iffan Maflahah, Linggar larasati, Burhan 


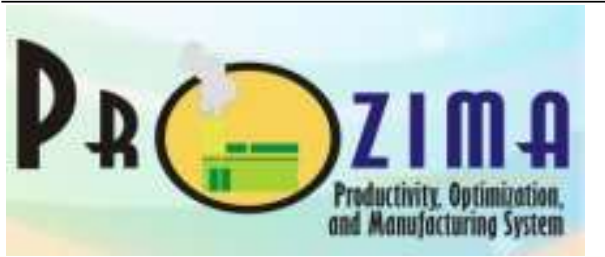

Prozima : Vol. 5, No. 2, Desember 2021, 1-12

E-ISSN. 2541-5115

Journal Homepage: http://ojs.umsida.ac.id/index.php/prozima

DOI Link: http://doi.org/10.21070/prozima.v5i2.1530

Article DOI: http://doi.org/10.21070/prozima.v5i2.1530

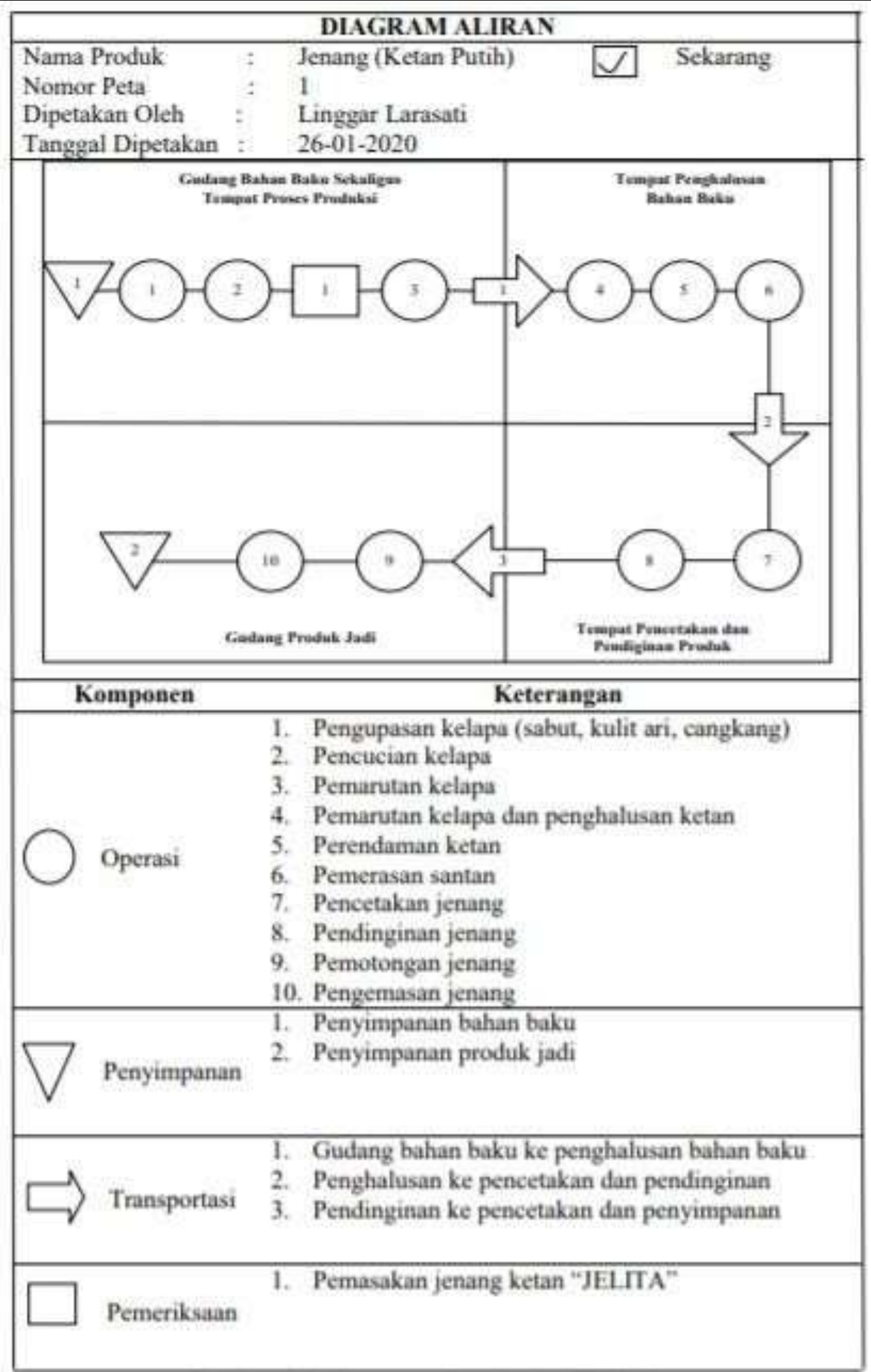

Gambar 1. Diagram Aliran Fasilitas Produksi Jenang Ketan "Jelita" Konsidi Sekarang

Analisis Waktu Baku Bagian Pemotongan dan Pengemasan Jenang Ketan "JELITA"/ Iffan Maflahah, Linggar larasati, Burhan 


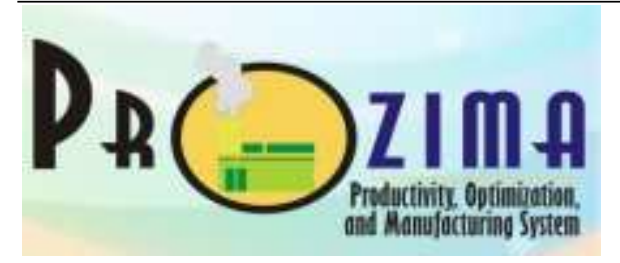

Prozima : Vol. 5, No. 2, Desember 2021, 1-12

E-ISSN. 2541-5115

Journal Homepage: http://ojs.umsida.ac.id/index.php/prozima

DOI Link: http://doi.org/10.21070/prozima.v5i2.1530

Article DOI: http://doi.org/10.21070/prozima.v5i2.1530

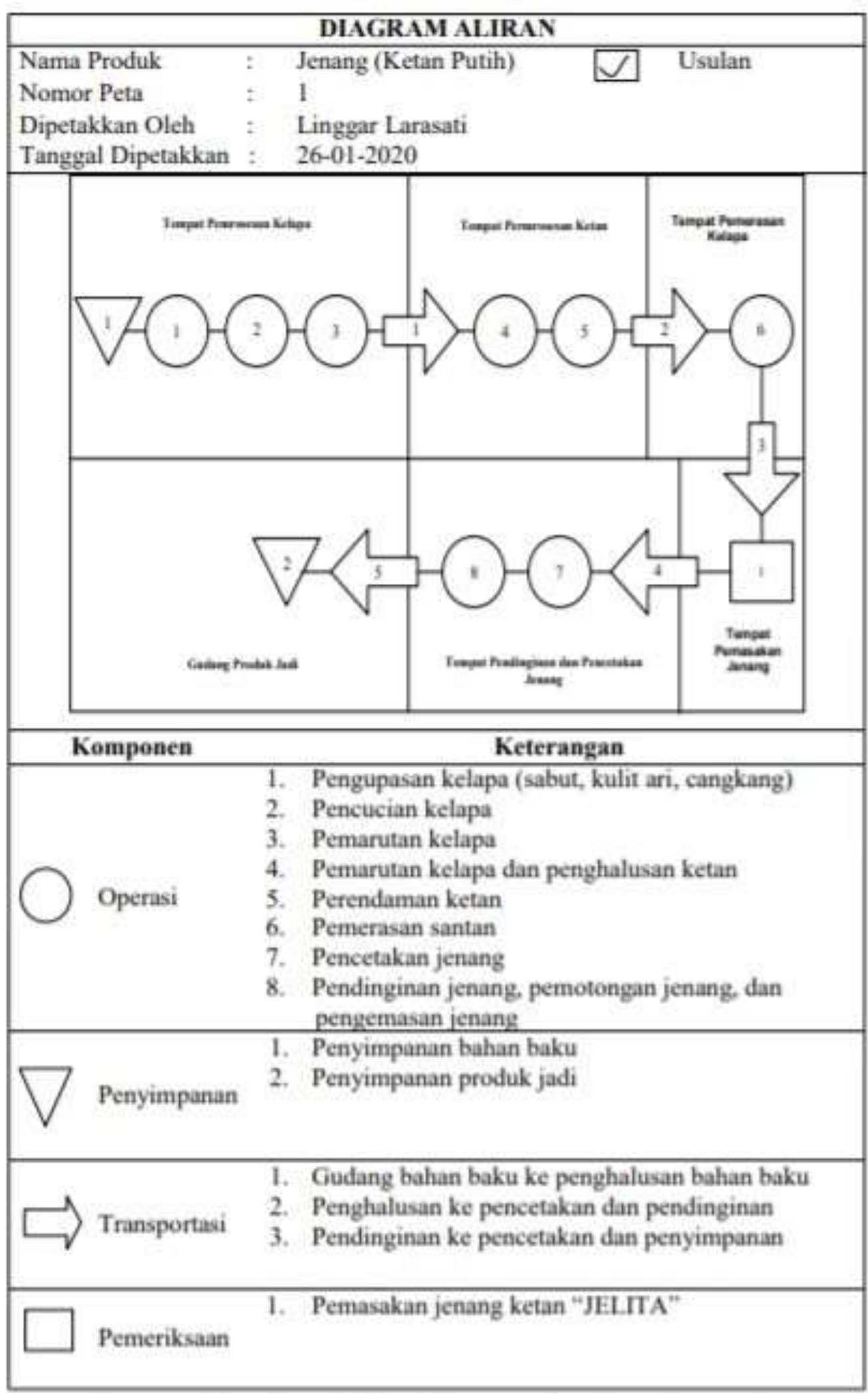

Gambar 2. Diagram Aliran Fasiitas Produksi Jenang Ketan “Jelita” Konisi Usulan

Analisis Waktu Baku Bagian Pemotongan dan Pengemasan Jenang Ketan "JELITA"/ Iffan Maflahah, Linggar larasati, Burhan 
Prozima : Vol. 5, No. 2, Desember 2021, 1-12

E-ISSN. 2541-5115

Journal Homepage: http://ojs.umsida.ac.id/index.php/prozima

DOI Link: http://doi.org/10.21070/prozima.v5i2.1530

Article DOI: http://doi.org/10.21070/prozima.v5i2.1530

\section{Peta Tangan Kiri dan Tangan Kanan Pemotongan dan Pengemasan}

Peta kerja tangan kiri dan tangan kanan pada proses pemotongan dan pengemasan jenang ketan dilakukan berdasarkan studi gerakan. Studi gerakan digunakan sebagai penentu efektifitas dan efisiensi gerakan ketika melakukan operasi [10]. Selain itu, elemen gerakan pada peta kerja tangan kiri dan tangan kanan diuraikan berdasarkan gerakan Therblig sebagai penentuan efektifitas gerakan yang dilakukan [11]. Peta tangan kiri dan tangan kanan termasuk kedalam peta kerja yang dapat membantu dalam penentuan waktu baku dan juga usulan perbaikan dalam suatu metode kerja [2].

Peta tangan kiri dan tangan kanan proses pemotongan jenang ketan "JELITA" pada kondisi sekarang dapat dilihat pada Tabel 1. Jumlah produk yang dipotong tiap siklus sebanyak 16 bungkus plastik (berat produk 500 gram). Jenang dikemas dengan kemasan plastik sebagai kemasan primer yang kemudian dikemas dengan menggunakan kemasan karton sebagai kemasan sekunder. Jumlah waktu tiap siklus pemotongan jenang ketan "JELITA" yaitu 76 detik dengan waktu untuk membuat satu potong jenang yaitu 4,75 detik

Tabel 1. Peta Tangan Kiri dan Tangan Kanan Bagian Pemotongan

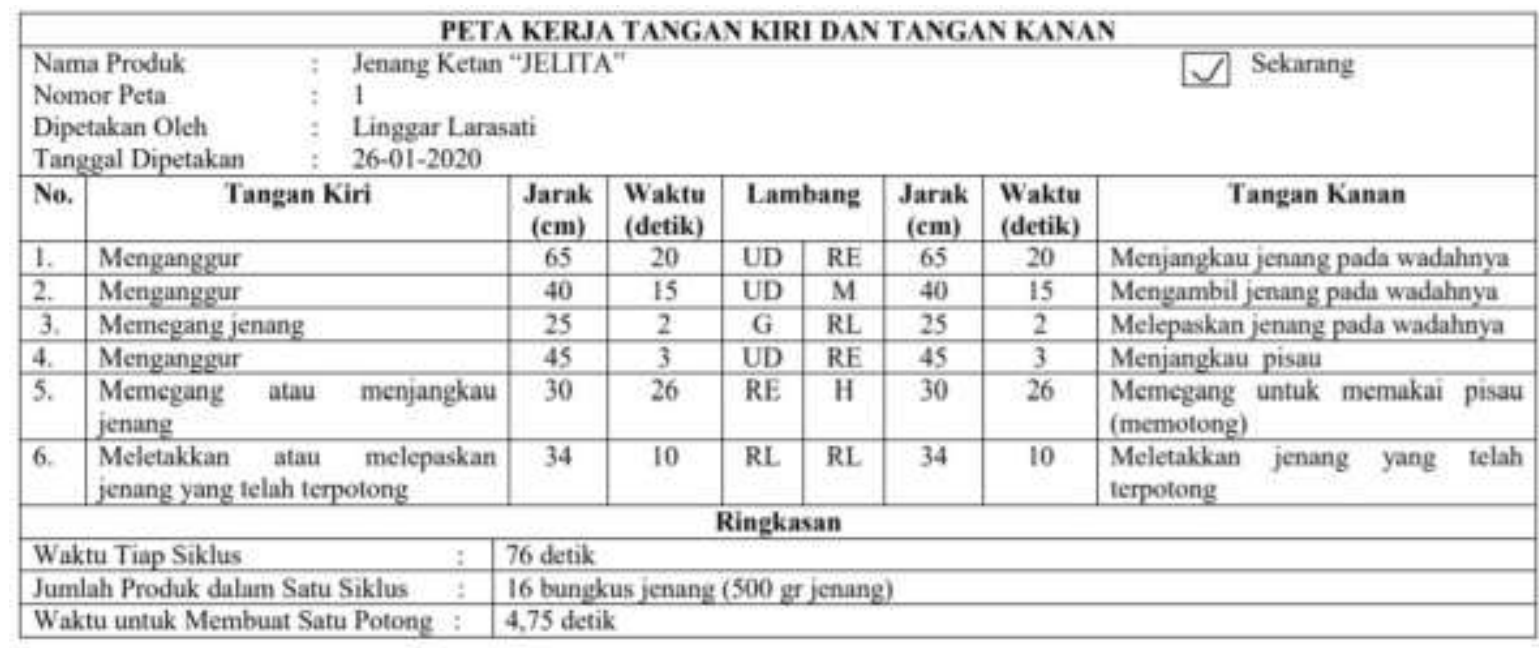

Pada proses pemotongan jenang ketan "JELITA" terjadi ketidakseimbangan elemen gerakan kerja antara tangan kiri dan tangan kanan. Hal tersebut ditunjukkan dengan waktu menganggur pada tangan kiri yang lebih mendominasi. Tangan kanan tidak terdapat waktu menganggur. Tangan kanan selalu melakukan proses kerja (pemotongan jenang) sehingga pada elemen gerakan kerja pada tangan kiri lebih banyak dibandingkan dengan tangan kanan. Hal tersebutlah yang dapat memicu ketidakseimbangan elemen gerakan yang terjadi pada proses pemotongan jenang. Oleh sebab itu, pada bagian pemotongan jenang ketan "JELITA" perlu dilakukan usulan perbaikan.

Usulan perbaikan yang dapat dilakukan berdasarkan elemen gerakan yang dilakukan pekerja atau berdasarkan ekonomi gerakan. Gerakan tersebut digunakan dalam penentuan gerakan efektif dan gerakan yang tidak efektif yang diuraikan dalam peta tangan kiri dan kanan.

Usulan perbaikan proses pemotongan disajikan pada peta tangan kanan tangan kiri yang tertera pada Tabel 2.

Analisis Waktu Baku Bagian Pemotongan dan Pengemasan Jenang Ketan "JELITA"/ Iffan Maflahah, Linggar larasati, Burhan 


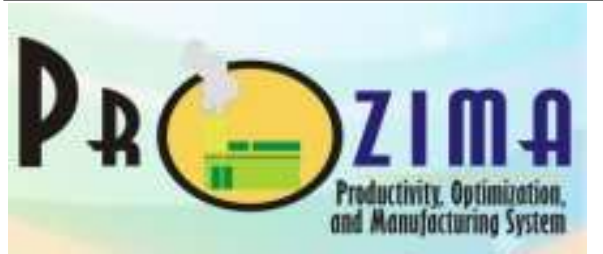

Prozima : Vol. 5, No. 2, Desember 2021, 1-12

E-ISSN. 2541-5115

Journal Homepage: http://ojs.umsida.ac.id/index.php/prozima

DOI Link: http://doi.org/10.21070/prozima.v5i2.1530

Article DOI: http://doi.org/10.21070/prozima.v5i2.1530

Tabel 2. Peta Tangan Kiri dan Tangan Kanan Bagian Pemotong Usulan

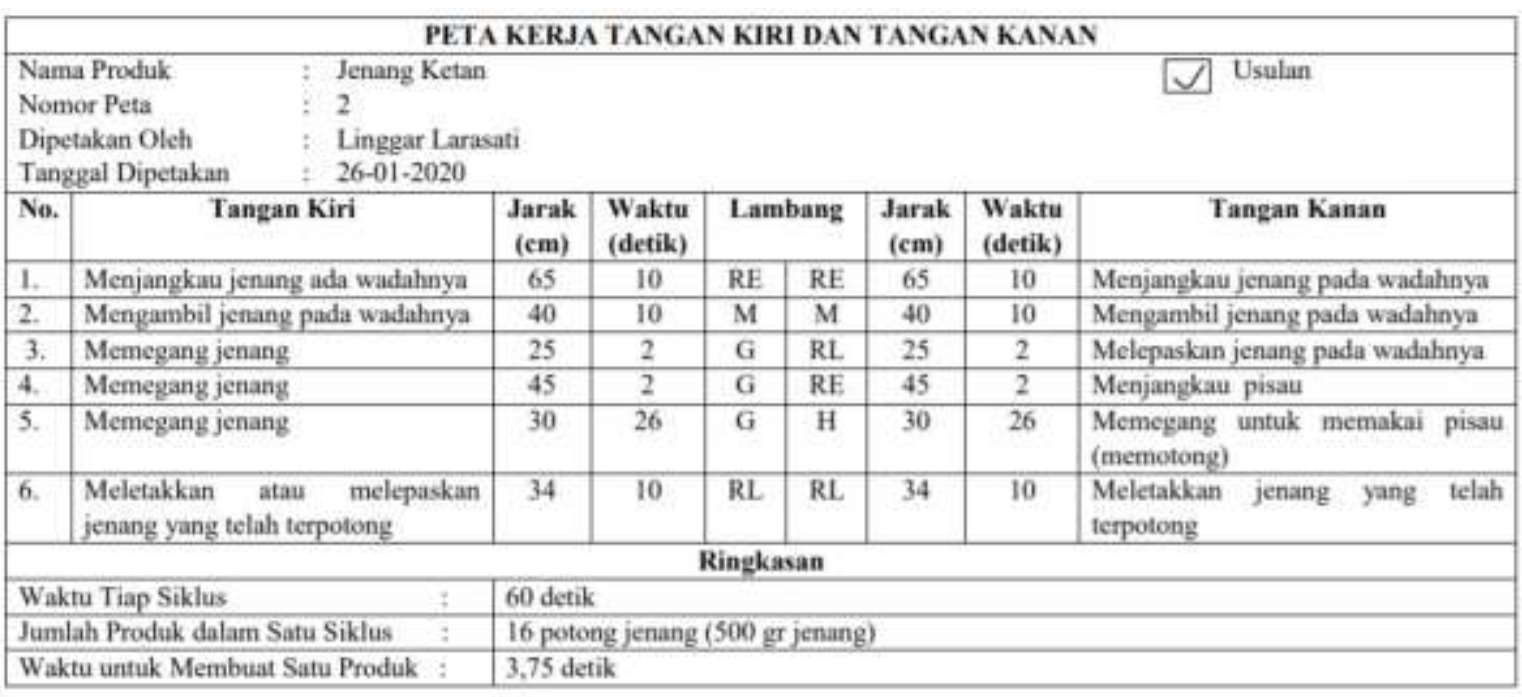

Usulan yang dilakukan yaitu mengurangi kegiatan menganggur saat pemotongan jenang ketan agar tercipta keseimbangan gerakan antara tangan kiri dan tangan kanan. Hal tersebut ditunjukkan efektifitas gerakan antara tangan kiri dan tangan kanan dibuktikan dengan tidak adanya kegiatan menganggur. Selain itu, pekerjaan yang dilakukan antara tangan kiri dan tangan kanan dimulai dan diakhiri dalam waktu yang bersamaan.

Waktu tiap siklusnya sebesar 60 detik dengan jumlah produk yang dihasilkan dalam satu siklusnya sebanyak 16 potongan (berat 500 gram). Kemudian besarnya waktu untuk membuat satu potong jenang yaitu 3,75 detik. Waktu penyelesaian lebih cepat dari peta kerja tangan kiri dan tangan kanan sebelum dilakukan usulan perbaikan sebesar 4.75 detik Percepatan waktu tersebut dihasilkan dari pengurangan gerakan yang tidak efektif pada gerakan yang dilakukan tangan kiri tau tangan kanan.

Proses pengemasan jenang ketan "JELITA", proses pengemasan jenang ketan "JELITA" yang dapat dilihat pada Tabel 3. menunjukkan bahwa elemen gerakan yang dilakukan dikatakan efisien dan seimbang antara tangan kiri dan tangan kanan.

Tabel 3. Peta Tangan Kiri dan Tangan Kanan Bagian Pengemasan

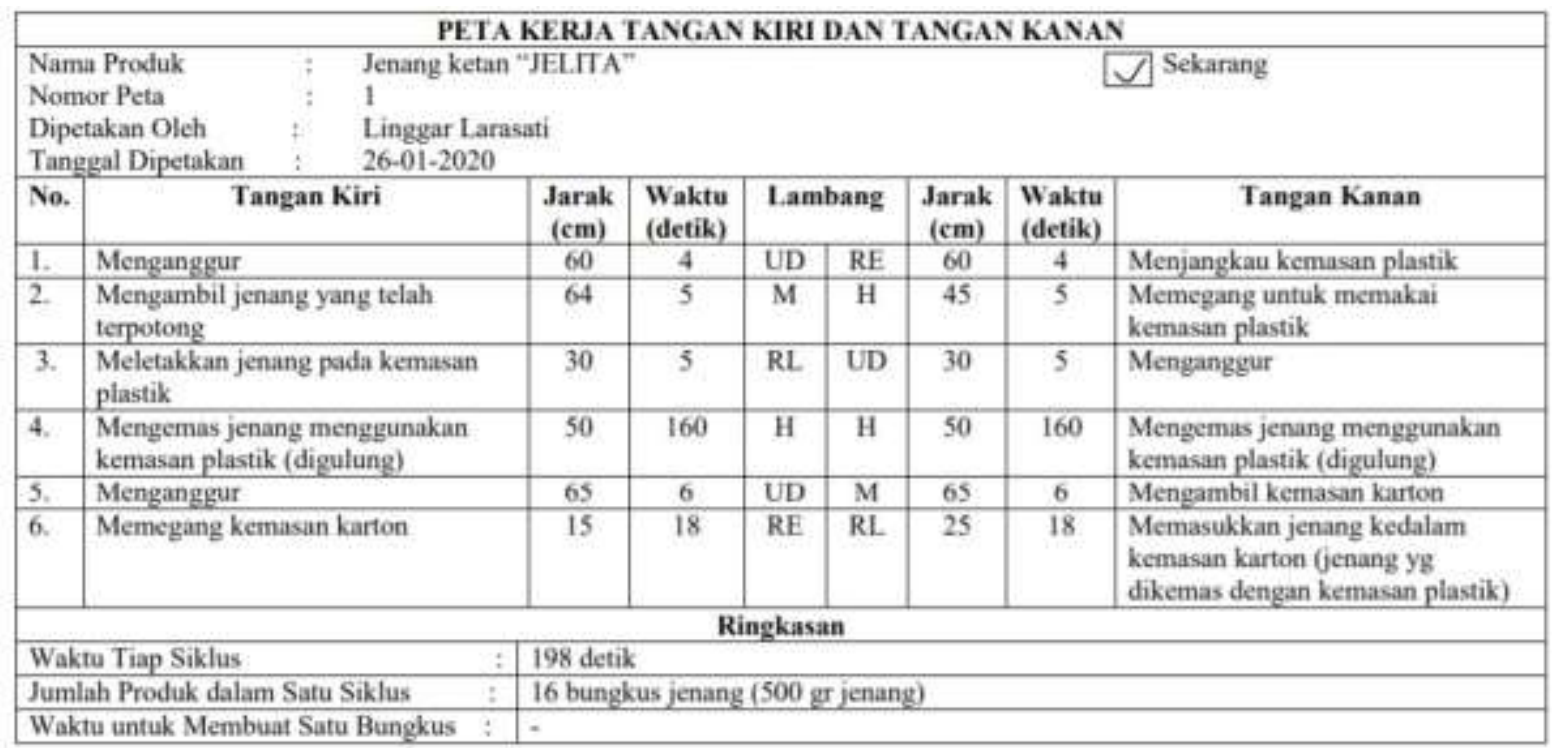

Waktu menganggur antara tangan kiri dan tangan kanan pada proses pengemasan jenang tidak terlalu mendominasi antara kedua gerakan tangan yang melakukan kegiatan pengemasan. Proses pemotongan jenang ketan "JELITA" hanya terdapat satu kali menganggur yaitu pada bagian tangan kiri dan tangan kanan

Analisis Waktu Baku Bagian Pemotongan dan Pengemasan Jenang Ketan "JELITA"/ Iffan Maflahah, Linggar larasati, Burhan 


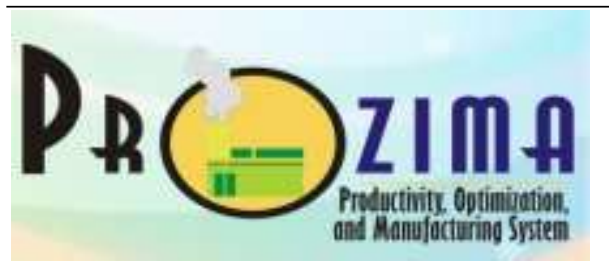

Prozima : Vol. 5, No. 2, Desember 2021, 1-12

E-ISSN. 2541-5115

Journal Homepage: http://ojs.umsida.ac.id/index.php/prozima

DOI Link: http://doi.org/10.21070/prozima.v5i2.1530

Article DOI: http://doi.org/10.21070/prozima.v5i2.1530

melakukan kegiatan menjangkau kemasan plastik. Tangan kanan juga terdapat waktu menganggur ketika tangan kiri melakukan proses meletakkan jenang pada kemasan plastik. Waktu tiap siklus sebesar 198 detik dalam proses pengemasan jenang sebanyak 16 bungkus (500 gram). Peta kerja tangan kiri dan tangan kanan pada proses pengemasan jenang ketan "JELITA" waktu dalam proses pembuatan satu produk jenang tidak dihitung. Hal tersebut dikarenakan dalam proses pengemasan jenang ketan "JELITA" terdapat dua proses kerja. Proses kerja tersebut yaitu pengemasan jenang ke dalam kemasan plastik sebagai kemasan primer dan pengemasan jenang ke dalam kemasan kotak sebagai kemasan sekunder.

Usulan perbaikan yang dilakukan pada peta tangan kiri dan tangan kanan proses pemotongan menghasilkan penggabungan elemen gerakan serta percepatan waktu tiap potongan jenang ketan "JELITA". Perbaikan pada proses pemotongan jenang ketan "JELITA" yaitu penghilangan kegiatan menganggur yang dominan dilakukan oleh tangan kiri sedangkan tangan kanan selalu melakukan gerakan. Peta tangan kanan tangan kiri usulan perbaikan proses pengemasan jenang "JELITA" dapat dilihat pada Tabel 4.

Tabel 4. Peta Tangan Kanan Kiri untuk Usulan Perbaikan Proses Pengemasan Jenang "Jelita"

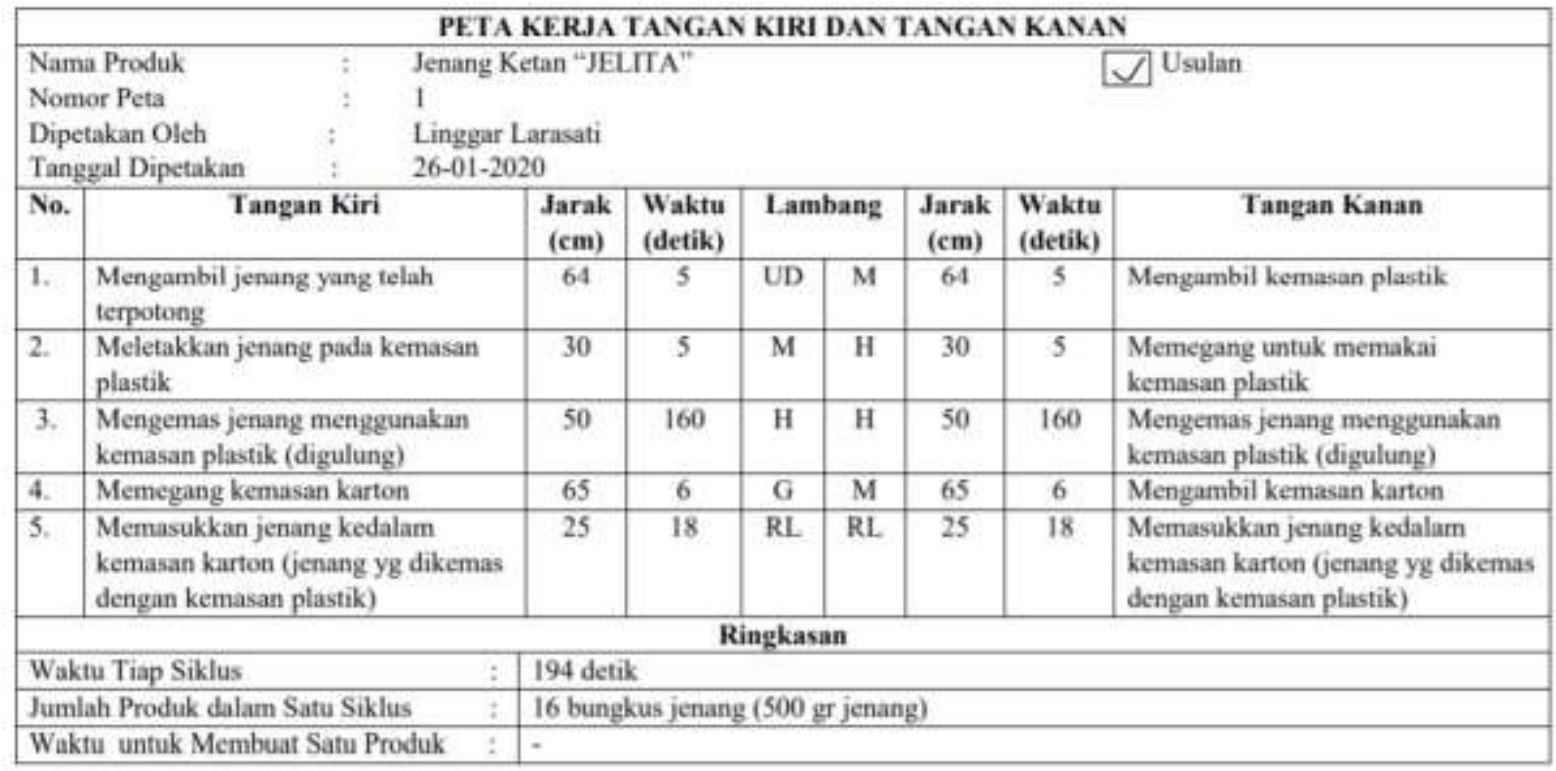

Peta tangan kiri dan tangan kanan pada proses pengemasan jenang ketan "JELITA" menghasilkan usulan yaitu menghasilkan penggabungan gerakan yang menyebabkan percepatan waktu tiap siklus. Waktu tiap siklus yang dihasilkan sebesar 194 detik. Waktu tersebut lebih cepat dari sebelum perbaikan yaitu sebesar 198 detik. Waktu membuat satu potongan jenang ketan "JELITA" tidak ditentukan dikarenakan dalam peta kerja tangan kiri dan tangan kanan terdapat dua proses. Proses tersebut yaitu pengemasan dengan kemasan plastik sebagai kemasan primer dan kemasan karton sebagai kemasan sekunder.

Waktu pengemasan jenang setelah dilakukan perbaikan menjadi lebih cepat yaitu waktu tiap siklus 194 detik (4 detik lebih cepat) dari peta tangan kiri dan tangan kanan sebelum dilakukan usulan sebesar 198 detik yang dapat dilihat pada Tabel 4.2. Selain itu, antara tangan kiri dan tangan kanan tidak ada kegiatan menganggur. Penggabungan operasi dan elemen gerakan juga dilakukan sebagai upaya untuk efektivitas dan efisiensi gerakan tangan kiri dan tangan kanan yang dilakukan pada proses pengemasan. Penggabungan yang dimaksud yaitu proses mengambil jenang ketan yang telah terpotong yang dilakukan tangan kiri bersamaan dengan menjangkau kemasan plastik dengan tangan kanan.

\section{Penentuan waktu baku}

Penentuan waktu baku di industri "JELITA" digunakan untuk menentukan rancangan kerja terbaik berdasarkan sistem kerjanya [20]. Penentuan waktu baku dilakukan hanya pada proses pemotongan dan pengemasan jenang ketan "JELITA". Hal tersebut dikarekan pada proses pemotongan dan pengemasan jenang ketan "JELITA" merupakan penentu keseragaman produk dan penentu kualitas produk yang disimpan.

Analisis Waktu Baku Bagian Pemotongan dan Pengemasan Jenang Ketan "JELITA"/ Iffan Maflahah, Linggar larasati, Burhan 


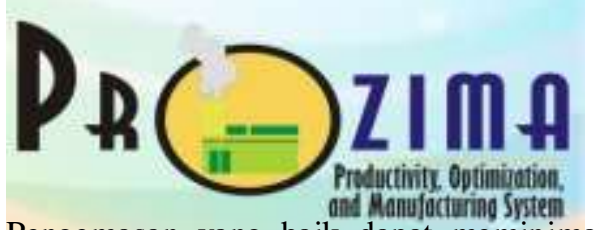

Prozima : Vol. 5, No. 2, Desember 2021, 1-12

E-ISSN. 2541-5115

Journal Homepage: http://ojs.umsida.ac.id/index.php/prozima

DOI Link: http://doi.org/10.21070/prozima.v5i2.1530

Article DOI: http://doi.org/10.21070/prozima.v5i2.1530

Pengemasan yang baik dapat meminimalisasikan tingkat ketengikan produk. Menurut [9] penelitian terkait dengan penentuan dapat dilakukan pada proses yang paling berpengaruh terkait dengan kualitas sampai dengan kuantias produk yang dihasilkan. Oleh sebab itu, proses pemotongan dan pengemasan jenang ketan "JELITA" merupakan faktor penting.

a. Pemotongan Jenang Ketan "JELITA"

Penentuan waktu baku pada proses pemotongan jenang ketan dilakukan dengan menentukan kecukupan data dan keseragaman data. Kecukupan data dilakukan dengan melakukan pengujian terkait dengan banyaknya data yang diambil sebanyak 200 data

Kecukupan data $\left(N^{\prime}\right)$ :

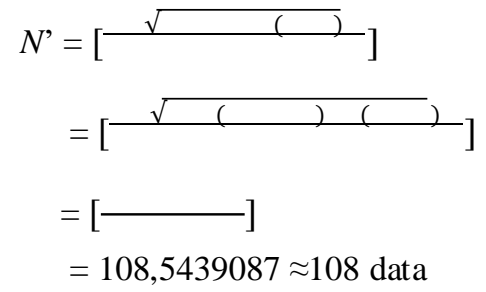

Penentuan keseragaman data tidak lepas dari penentuan homogenitas sebaran data. Keseragaman data dilakukan dengan penentuan BKA dan BKB. Gambar 3 menunjukkan bahwa data yang diambil telah memenuhi syarat keseragaman data. Hal tersebut dikarenakan keseluruhan data yang di uji telah berada di dalam BKA dan BKB.

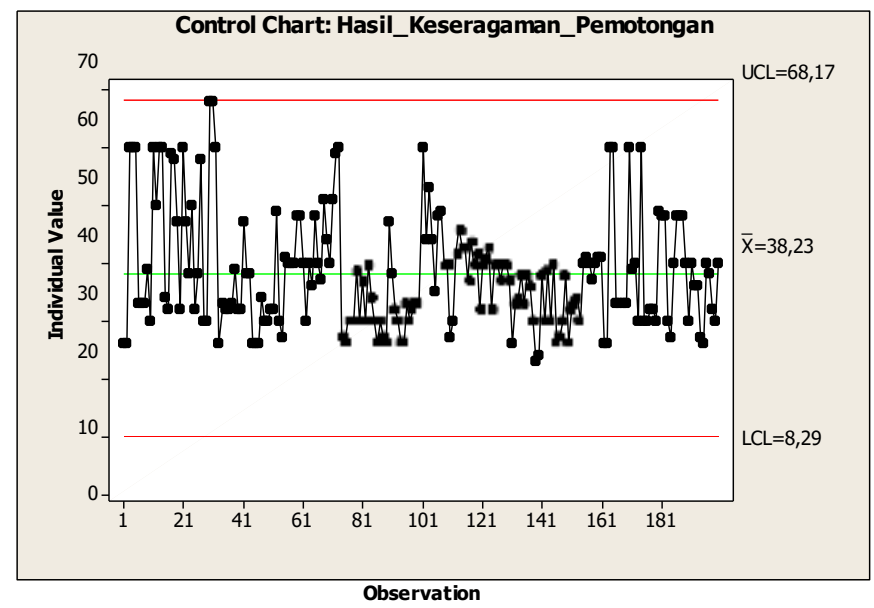

Sumber: Data Primer Di Olah, 2020

Gambar 3. Keseragaman Data Bagian Pemotongan

Penentuan waktu baku dalam proses pemotongan juga ditentukan berdasarkan penentuan waktu siklus sampai dengan penentuan kelonggaran yang dapat dilihat pada Tabel 5

Tabel 5. Waktu Baku pada Proses Pemotongan jenang Ketan "Jelita"

\begin{tabular}{cc}
\hline Parameter Perhitungan & Pemotongan \\
\hline Waktu Silkus (detik) & 38 \\
Faktor Penyesuaian & 1,14 \\
Waktu Normal (detik) & 43 \\
Kelonggaran (\%) & 18 \\
Waktu Baku (detik) & 52 \\
\hline
\end{tabular}

b. Pengemasan Jenang Ketan "JELITA"

[6] dalam penelitiannya, proses pengemasan jenang yang baik dapat memperpanjang umur simpan produk yang didasarkan pada waktu standar agar proses pengemasan dapat memenuhi target pelanggan.

Analisis Waktu Baku Bagian Pemotongan dan Pengemasan Jenang Ketan "JELITA"/ Iffan Maflahah, Linggar larasati, Burhan 


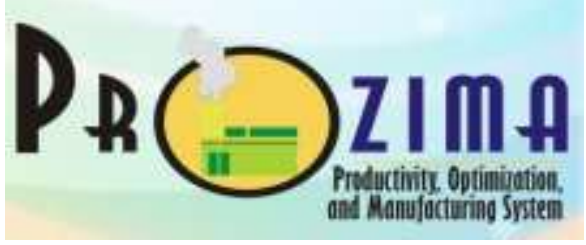

Prozima : Vol. 5, No. 2, Desember 2021, 1-12

E-ISSN. 2541-5115

Journal Homepage: http://ojs.umsida.ac.id/index.php/prozima

DOI Link: http://doi.org/10.21070/prozima.v5i2.1530

Article DOI: http://doi.org/10.21070/prozima.v5i2.1530

Penentuan waktu baku pada proses pengemasan memiliki langkah-langkah yang sama dengan proses pemotongan jenang ketan dengan jumlah data pengamatan sebanyak 200 data.

Kecukupan Data $\left(N^{\prime}\right)$ :

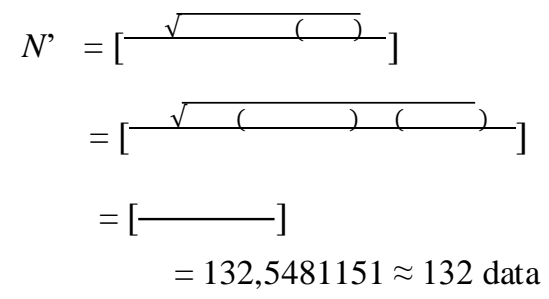

Keseragaman data pada proses pengemasan jenang ketan "JELITA" dapat dilihat pada Gambar 4.

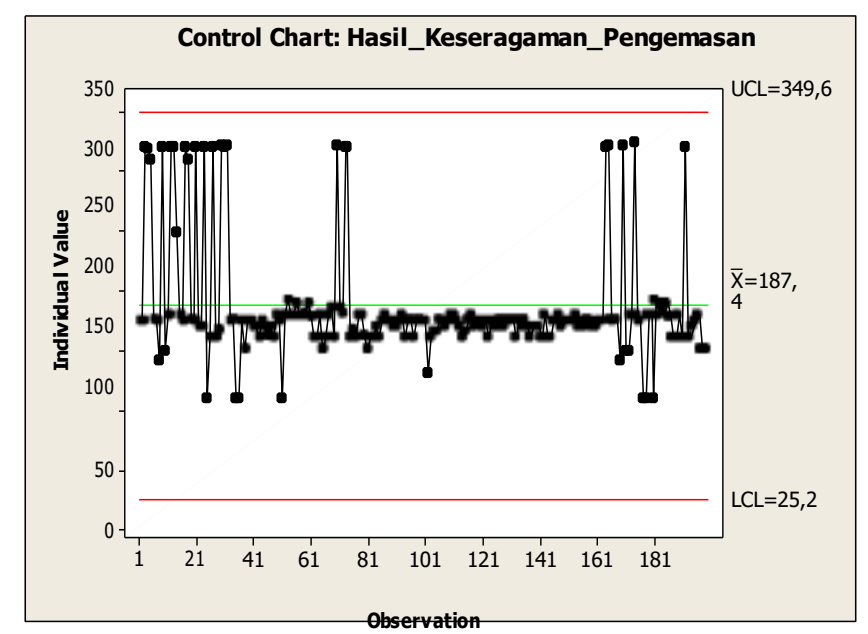

Sumber: Data Primer di Olah, 2020

Gambar 4. Keseragaman Data Bagian Pengemasan

Penentuan waktu baku pada bagian pengemasan dilakukan untuk menghasilkan metode, tempat sampai dengan waktu terbaik yang digunakan dalam suatu proses produksi. [12] menyebutkan bahwa waktu baku yang telah ditentukan dapat digunakan sebagai standar waktu untuk proses produksi. Selain itu, hasil penentuan waktu baku ini juga dapat digunakan sebagai penentu kualitas dan kuantitas hasil produksi [5] Hasil penentuan waktu baku proses pengemasan dapat dilihat pada Tabel 6.

Tabel 6 Waktu Baku pada Proses Pengemasan Jenang Ketan "Jelita"

\begin{tabular}{cc}
\hline Parameter Perhitungan & Pemotongan \\
\hline Waktu Silkus (detik) & 187 \\
Faktor Penyesuaian & 1,08 \\
Waktu Normal (detik) & 202 \\
Kelonggaran (\%) & 12 \\
Waktu Baku (detik) & 226 \\
\hline
\end{tabular}

\section{KESIMPULAN}

Analisis metode kerja di industri "JELITA" berdasarkan perhitungan waktu baku pada proses pemotongan dan pengemasan telah diketahui standar waktu yang dapat digunakan oleh industri. Standar waktu tersebut yaitu 52 detik untuk proses pemotongan dan 226 detik untuk proses pengemasan. Perbaikan yang dilakukan menggunakan alat bantu berupa peta kerja sangat efektif dan efesien ketika di terapkan di industri "JELITA". Hal tersebut diketahui dengan adanya pengurangan proses yang tidak efektif sehingga waktu proses menjadi singkat dan dapat meningkatkan proses produksi jenang ketan (peta proses operasi dan peta kerja tangan kiri dan tangan kanan). Peta kerja berupa diagram aliran ruang gerak pekerja menjadi lebih efektif. Analisis Waktu Baku Bagian Pemotongan dan Pengemasan Jenang Ketan "JELITA"/ Iffan Maflahah, Linggar larasati, Burhan 
Prozima : Vol. 5, No. 2, Desember 2021, 1-12

E-ISSN. 2541-5115

Journal Homepage: http://ojs.umsida.ac.id/index.php/prozima

DOI Link: http://doi.org/10.21070/prozima.v5i2.1530

Article DOI: http://doi.org/10.21070/prozima.v5i2.1530

\section{DAFTAR PUSTAKA}

[1] Andriani, D. P., Industri, J. T., Teknik, F., \& Brawijaya, U. (2017). Penentuan Waktu Dan Output Baku Pada Proses Produksi Tube Lam Dengan Methods Time Measurement. Jurnal Sinergi. 21(3): 204-212.

[2] Bashori, H., \& Umami, R. (2015). Analisa Waktu Baku Produksi Dompet Dengan Pendekatan Peta Tangan Kiri Dan Tangan Kanan Pada CV. XYZ Di Pasuruan. Jurnal Sketsa Bisnis. 2(1): 18-27.

[3] Beauty, Y. V., \& Astuti, R. D. (2017). Perbaikan Metode Kerja Menggunakan Peta Tangan Kiri Tangan Untuk Meningkatkan Produktivitas Pada PT. BCD. Prosding Seminar Nasional IDEC.

[4] Hartanti, L. P. S. (2016). Work Measurement Appoach To Determine Standard Time In Assembly Line. International Journal of Management and Applied Science. 2(10): 192-195.

[5] Hidayat, N. S., Setiawan, I., \& Sitanggang, R. (2015). Aktivitas Kerja Operator Towing Carmel Melalui Penentuan Waktu Baku. Jurnal Manajemen Bisnis Transportasi Dan Logistik. 2(1): 91-111.

[6] Kusumaningrum, A., Ariani, D., Khasanah, Y., Penelitian, B., \& Bahan, T. (2017). Pengaruh waktu penyimpanan terhadap karakteristik makanan tradisional " jenang saban" effects of storage period to traditional food " jenang saban ". Jurnal Penelitian Teknologi Industri. 9(1): 23-36.

[7] Maryana, \& Meutia, S. (2015). Perbaikan Meotde Kerja Pada Bagian Produksi Dengan Menggunakan Man And Machine Chart. Jurnal Teknovasi. 2(2): 15-26.

[8] Muluk, R. K. A. (2019). Penentuan Waktu Baku Dalam Pembuatan Kotak Alat Pembaca Pengukuran Melalui Motion Study. Jurnal Saintek. 1(1): 49-56.

[9] Norita, D., Didi, J., Hutasoit, J., \& Wijaningrum, P. (2018). Pengukuran Waktu Baku Proses Mixing, Filling, Dan Packing Mood Menggunakan Metode Pengkukuran Waktu Jam Henti Di PT. X. Jurnal Teknokris. 12(1): 15-21.

[10] Nurhasanah, D., Mawarni, W., \& Ginantaka, A. (2016). Analisis Elemen Gerakan Pada Proses Pengupasan Kulit Ubi Dengan Menggunakan Studi Gerak Dan Wktu Untuk Meningkatkan Efisiensi Kerja. Jurnal Pertanian. 7(1): 28-34.

[11] Piranti, A. (2018). Analisis Elemen Gerakan Kerja untuk Menetapkan Waktu Baku. Yogyakarta: Universitas Sumatra Utara Medan.

[12] Rinawati, D. I., Puspitasari, D., \& Muljadi, F. (2012). Penentuan Waktu Standar Dan Jumlah Tenaga Kerja Optimal Pada Produksi Batik Cap (Studi Kasus: IKM Batik Saud Effendy, Leweyan). Jurnal Jati Undip. 7(3): 143-150.

[13] Sari, E. M., \& Darmawan, M. M. (2020). Pengukuran Waktu Baku Dan Analisis Beban Kerja Pada Proses Filling Dan Packing Produk Lulur Mandi Di PT. Glora Origita Cosmetics. Jurnal Ilmiah Rekayasa Dan Inovasi. 2(1): 51-61.

[14] Singh, M. P., \& Yadav, H. (2016). Improvement In Proccess Industries By Using Work Study Methods: A Case Study. International Journal of Mechanical and Technology. 7(3): 426-436.

[15] Sulistyadi, K., \& Susanti, S. L. (2003). Perancangan Sistem Kerja Dan Ergonomi. Jakarta: Fakultas Universitas Sahid.

[16] Sutalaksana, I. Z., Ruhana, A., \& Tjakraatmaja, J. H. (2006). Tenik Perencanaan Sistem Kerja. Bandung: ITB.

[17] Tarigan, M. I. (2015). Pengukuran standar waktu kerja untuk menentukan jumlah tenaga kerja optimal. Jurnal Wahana Inovasi. 4(1): 26-35.

[18] Wignjosoebroto, S. (2008). Ergonomi Studi Gerakan Dan Waktu. Surabay: Guna Widya.

[19] Wignjosoebroto, S. (2009). Tata Letak Dan Pemindahan Bahan. Surabaya: Guna Widya.

[20] Zulaeha, S. S., Ramadayanti, M., Said, N. A., \& Nurhayati, I. (2016). Pengukuran Waktu Kerja Baku Pada Proses Pembuatan Roti. Jurnal Agroindustri Halal. 2(1): 24-30.

Analisis Waktu Baku Bagian Pemotongan dan Pengemasan Jenang Ketan "JELITA"/ Iffan Maflahah, Linggar larasati, Burhan 